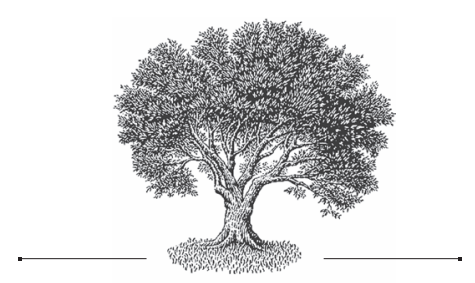

\section{Критика иностранной} литературы на

страницах советского

оборонного журнала «ЫОКАФ»:

\section{Как не стать Ремарком*}

The Soviet Journal LOKAF on Foreign Literature: How not to Become Remarquable

\section{Алда Олеговна Бурцева}

Независимый исследователь, Москва, Россия

\author{
Alla O. Burtseva \\ Independent scholar, \\ Moscow, Russia
}

\title{
Резюме
}

Статья посвящена работе редакции советского журнала «ДОКАФ» (будущее «Знамя») с произведениями иностранных писателей в начале 1930-х гг. в контексте военной пропаганды в литературе. Опубликованные переводы и комментарии к ним рассматриваются как фактор формирования канона советской оборонной дитературы. Из числа прочих иностранных писателей выделялись Э. М. Ремарк и Ч. Гаррисон, чьи тексты выходили с краткими редакционными предисловиями. В центре внимания редакции оказались романы «Der Weg zurück» и «Generals Die in Bed». Авторов обвиняли

* Исследование выполнено при финансовой поддержке РФФИ в рамках научного проекта № 20-012-00549 А. Благодарю Д. Г. Полонского и А. С. Федотова за ценные замечания по поводу этой статьи.

Funding: The reported study was funded by RFBR, project number 20-012-00549 A.

Цит ирован ие: Буриева А. О. Критика иностранной литературы на страницах советского оборонного журнала «ЛОКАФ»: как не стать Ремарком // Slověne. 2021. Vol. 10, № 1. C. 347-367.

Citation: Burtseva A. (2021) The Soviet Journal LOKAF on Foreign Literature: How not to Become Remarquable. Slověne, Vol. 10, № 1, p. 347-367.

DOI: $10.31168 / 2305-6754.2021 .10 .1 .15$ 
в так называемом «ремаркизме». Эта дефиниция затем вышла далеко за пределы критики иностранной литературы. Необходимость предисловий была мотивирована тем, что советский автор должен был обучаться на отрицательных примерах, создавая собственные произведения с огдядкой на них. Творчество Ремарка систематически оценивалось негативно, непонимание истоков «империалистической войны», «пацифизм» и «буржуазный гуманизм» ставились в вину автору. Ситуация с Гаррисоном была несколько сложнее, в его лице нужно было продемонстрировать советскому автору писателя, который постепенно эволюционирует к «пролетарскому художнику». Такие оценочные понятия, как «пацифизм», «гуманизм», «ремаркизм» и прочие, представляли собой характерные риторические приемы, призванные наметить для советского писателя необходимые ориентиры. При этом сами понятия выходили за пределы литературно-критического поля и представляли собой, по существу, часть общего идеологического фона в военной пропаганде 1930-х гг.

Ключевые слова

советская оборонная литература, пропаганда в литературе, ЛОКАФ, ремаркизм, Э. М. Ремарк, Ч. Гаррисон, история советской дитературной критики

\section{Abstract}

The article deals with the editorial work of the Soviet literary journal LOKAF (the future Znamia) considering foreign writers in the early 1930s in the context of military propaganda in literature. Translations published in $L O K A F$ and the commentaries on them are considered as a factor of Soviet defense literature (as the members of Literary Assotiation of Red Army and Navy called it) canon formation. Among other foreign writers Erich Maria Remarque and Charles Harrison were out in the specific light. Their works (particularly Der Weg zurück and Generals Die in Bed) were given special attention. The writers were accused of so-called "remarquism", and this concept expanded beyond the borders of foreign literature. The necessity for editorial notes was motivated by the viewpoint that Soviet defense authors had to learn from negative examples and take them into account. Remarque systematically received harsh criticism. He was accused of misunderstanding "imperialistic war", "pacifism" and "bourgeoise humanism". The situation of Harrison was more complicated. He was considered as an author who gradually evolves towards "proletarian artist". The concepts of "pacifism", "humanism", "remarquism" and others formed specific rhetorical patterns and had to show the Soviet defense authors landmarks to go by. These definitions moved beyond literature itself and were at fact a part of the whole ideological background in the military propaganda of the 1930s.

Keywords

Soviet defense literature, literary propaganda, LOKAF, remarquism, Erich Maria Remarque, Charles Harrison, Soviet literary criticism 
Журнал «ЛОКАФ», позднее переименованный в «Знамя», был основным органом одноименной литературной организации в СССР в 1930-е гг. ЛОКАФ, т. е. Литературное объединение Красной Армии и Флота, был сформирован в 1930 г. в ответ на государственный запрос на так называемую «оборонную литературу» (как ее называли сами члены объединения). Круг людей, входящих в ЛОКАФ, объединяла задача с помощью литературы «крепить оборону страны». С этой целью, с одной стороны, к созданию оборонной литературы привлекались профессиональные авторы и литературные критики, с другой - создавались литературные кружки в частях РККА. Тематика оборонных произведений не обязательно должна была быть сугубо военной, однако подразумевалось, что, создавая и потребляя специальные тексты, советский писатель и читатель готовятся к будущей войне.

Организационная деятельность объединения затрагивалась в работах Е. А. Добренко [1993; 2000], 3. С. Закружной [2019; см. также Закружная, Московская 2018], А. В. Сысоевой [2019; 2020], однако подробного анализа структура журнала «ЛОКАФ» до его переименования в «Знамя» не получала. Существует, однако, гипотеза, согласно которой деятельность объединения и одноименного журнала стала одним из истоков формирования соцреалистического канона ${ }^{1}$ [Добренко 2000; Закружная 2019]. Вместе с тем оборонная литература жила по своим внутренним законам и формировала свой набор канонических авторов.

В современных исследованиях история ЛОКАФ ведется от обращения группы писателей, которое было напечатано в «Литературной газете» 26 июня 1930 г. под характерным заглавием «Красная армия ждет своего писателя» [Закружная, Московская 2018: 13]. Добренко справедливо замечает, что объединение было сформировано не на пустом месте:

1 Говоря о каноне, мы в первую очередь имеем в виду так называемый соцреалистический канон, как он обозначен в одноименной сборнике; см. [Гюнтер, Добренко 2000]. Речь идет в большей степени о советском идеологическом проекте, нежели о списке «образцовой» литературы, уже набравшей культурный капитал, как это понимают социологические теории канона (см., например, [Guillory 1993]). Это не означает, что советская литература не была подвержена институциональной канонизации через, например, школу (см. [Malygin 2012]) или систему премирования. Однако для соцреалистического канона оказывается решающей нормативная эстетика. При этом, как кажется, такие организации, как ЛОКАФ или РАПП, претендовали на то, чтобы поучаствовать в становлении канона и формировании этой эстетики. Оборонная литература была в этом смысле достаточно продуктивна и позднее нашла свое место в соцреалистическом дискурсе. Тем не менее и здесь имеет смысл говорить о канонизированных авторах или текстах (для оборонной литературы это в первую очередь произведения Дмитрия Фурманова). В статье из сборника «Соцреалистический канон» также была предпринята попытка применить к канону соцреализма теорию поля Пьера Бурдье [Геллер, Боден 2000; см. также Бурдье 2005]. Однако, как кажется, теория поля применительно к советской литературе должна работать в несколько иной схеме [Lovell 2000: 18-24]. 
ЛОКАФ явился сложным сплавом: если судить по составу деятелей, вошедших в его руководство, мы обнаружим здесь и деятелей РАППа, и Литфронта, и «Кузницы», и военно-политических институтов, и просто энтузиастов. Новая организационная структура еще до своего оформления имела достаточные материальные возможности для собственного периодического издания - альманаха «Залп», четыре «очереди» которого вышли в Ленинграде в 1930 году. Субсидировал издание ПУРККА (Политическое Управление Рабоче-Крестьянской Красной Армии), и эта связь с армейским политуправлением не только не камуфлируется, но, напротив, постоянно и с гордостью подчеркивается. Собственно, о связи говорить здесь, очевидно, не следует. Если взглянуть на коллективную фотографию членов Центрального Совета ЛОКАФ, то можно обнаружить лишь несколько человек в штатском все остальные были попросту военными журналистами или сотрудниками ПУРККА [Добренко 2000: 227].

Состав Центрального совета был, тем не менее, довольно обширен. Согласно публикации в «Литературной газете», туда вошли 48 человек [Кальм 1930; см. также Закружная, Московская 2018: 14], включая, например, Максима Горького, Всеволода Вишневского, Всеволода Мейерхольда, Демьяна Бедного. Мы не ставим перед собой задачу ответить на вопрос, насколько все эти «люди в штатском» (исключая Вишневского) реально были включены в активную деятельность ЛОКАФ. Однако стоит отметить, что среди прочих в составе совета упоминается Леонид Дегтярев - будущий ответственный редактор журнала, о котором пойдет речь.

В состав редакции также входили Мате Залка, Александр Исбах, Владимир Луговской, Сергей Мстиславский, Семен Рейзин, Павел Слесаренко, Александр Тарасов-Родионов, Степан Щипачев. Редакция строила большие планы по привлечению молодых авторов, формулируя свою позицию следующим образом (цитируем редакционное письмо, адресованное литкружковцам и опубликованное в номере 5-6 журнала):

Писатель красноармеец и краснофлотец имеет возможность непосредственно наблюдать все процессы, происходящие в Красной армии и флоте - opганизация социалистических форм труда, ударничество и соцсоревнование, вопросы боевой подготовки, одоление учебы, техники, помощь социалистическому строительству, рост классового сознания бойца. Наблюдает и теневые стороны - отдельные прорывы, проникновение классово чуждых элементов в сплоченный трудовой коллектив Красной армии и флота и т. п.

Нужно все это художественно показать, полностью осветить жизнь и быт Красной армии и флота, как кузницы, выковывающей борцов за социализм, тщательно подходя к каждому факту, к мельчайшим подробностям учебы, быта, ковки сознания, отмечая все процессы, все вопросы, стоящие в повест- 
ке сегодняшнего дня Красной армии. Показать теснейшую связь красноармейцев с трудящимися города и деревни, взаимопомощь, взаимодействие, общую борьбу за социализм [ЛОКАФ 1931/5-6].

Машинопись этого документа хранится в РГАЛИ (Ф. 618. Оп. 1. Ед. хр. 3. Л. 10-11) и содержит незначительные отличия. Так, для публикации в журнале были вставлены «вопросы боевой подготовки». Тематически они должны были стать одним из основных направлений очерков о бойцах-ударниках. Авторство письма установить не удается, машинопись завизирована инициалами «ЛД», что, по всей видимости, указывает на Л. Дегтярева.

Вопреки декларируемому поиску новых кадров, нельзя сказать, что непрофессиональные авторы в «ЛОКАФ» доминировали. На его страницах публиковались Всеволод Иванов, Владимир Луговской, Артем Веселый - уже достаточно опытные писатели. Тем не менее, критические разделы журнала адресовались писателю, который хотел войти в круг оборонных авторов и готов был пройти обучение или переобучение.

Именно «ЛОКАФ» имел все ресурсы, чтобы формировать основные тематические направления оборонной литературы, очерчивать круг авторов, задавать тон литературно-критических статей. Этим же задачам, как мы покажем, отвечала и критика на страницах журнала зарубежных авторов.

Предполагалось, что журнал будет состоять из нескольких разделов, и, как следует из протоколов заседаний редакции и переписки, его содержание пытались структурировать, однако происходило это с переменным успехом. В РГАЛИ в фонде редакции журнала «Знамя» хранится машинопись, датируемая началом 1931 г. Это обращение ко всем членам редколлегии. Автора по машинописи установить не удается, это мог быть как ответственный редактор (впрочем, в письме упоминается, что он в командировке), так и, например, Рейзин, активно участвовавший в планировании будущего журнала, или любой другой видный член ЛОКАФ. В письме говорится:

Начиная уже со второго номера, верстка журнала должна быть уточнена и само строение журнала должно стать более четким и органически завершенным. Для этого журналу необходимо, прежде всего, расчленение материала по рубрикам постоянных отделов. В первом номере это разделение произведено лишь механически, путем соответственного порядка расположения материала. При верстке второго номера крайне желательно иметь продуманные и утвержденные редколлегией постоянные заголовки отделов (по примеру «Красной Нови», «Октября», «Нового мира» и др.) [РГАЛИ. Ф. 618. Оп. 1. Ед. хр. 3. Л. 1]. 
Структура журнала вопреки желаниям редакции оставалась подвижной, однако неизменно выделялся литературно-критический раздел «На фронтах литературы» и переводной блок. Последний составлялся из произведений иностранных авторов в переводе на русский язык, иногда с небольшой редакционной справкой о публикуемом тексте. Выбор иностранных авторов был довольно широк, и редакция, очевидно, не руководствовалась идеей публиковать только нужных и «правильных» авторов. Одни тексты должны были стать примером для советского оборонного литератора, другие сигнализировали о том, на кого ни в коем случае нельзя быть похожим. Редакционная справка фактически объясняла читателю (и потенциальному автору оборонного текста), как следует оценивать то или иное произведение, опубликованное в журнале. Таким образом формировался круг по сути «антиканонических» текстов. В первый год существования журнала среди таких текстов оказались произведения Эриха Марии Ремарка и Чарльза Гаррисона, которые предварялись самыми крупными и наиболее риторически оформленными редакционными заметками. Авторов заметок нам пока установить не удалось.

Уже во втором номере «ЛОКАФ» за 1931 г. был опубликован отрывок из романа Ремарка «Der Weg zurück» под заголовком «Обратный путь» с пометой «Перевод с немецкого М. Зальдович и А. Гурлянд» (информации о переводчиках нам найти не удалось, сам текст перевода малоизвестен, он не упоминается ни в библиографиях, ни в исследованиях о творчестве Ремарка). Полностью роман был опубликован в том же 1931 г. в рижском издательстве «ORBIS», в 1933 г. он вышел на страницах журнала «Интернациональная литература» в номере 3 в переводе И. Горкиной, а в 1934 г. редакция оборонного журнала (тогда уже «Знамени») вновь обратилась к роману, напечатав его в номере 7 в том же переводе, что и в «Интернациональной литературе». Таким образом, перевод отрывков создавался специально для публикации в «ЛОКАФ» в 1931 г.

В редакционной заметке говорилось: «Новый роман Ремарка [...] продолжает и даже ухудшает "традиции" книги "На западе без перемен” [ЛОКАФ 1931/2: 81]. Упомянутый роман «На Западном фронте без перемен» занимал особое место в советском оборонном дискурсе. В 1930 г. он был даже включен в программу школы колхозной молодежи [Malygin 2012: Anhang 3], во втором мартовском выпуске ленинградского оборонного сборника «Первый Залп. Вторая очередь» Ремарк упоминается скорее в положительном контексте и ставится в один ряд с канонизированными уже Дмитрием Фурмановым и Александром Фадеевым: «Новые Фурмановы, молодые Фадеевы, советские Ремар- 
ки должны обогатить пролетарскую литературу ценнейшими художественными вкладами» [Поляк 1930: 3]. Однако вскоре советская литературная пропаганда (и в том числе «Залп», к тому времени ставший журналом, в номере 10 от 1931 г.) охарактеризовала роман как «пацифистский» и «империалистический» (показателен в этом отношении случай пьесы Вишневского «На Западе бой» (поставлена в 1933 г.), которая фактически была «ответом» на роман Ремарка). Наконец, именно в 1930-е гг. в советской литературной критике возникает понятие «ремаркизм», подразумевающее негативную оценку2 .

«Ремаркизм», как выяснилось, придумали вовсе не советские литературные критики. В июне 1930 г. в заметке Александра Лейтеса в «Литературной газете» была упомянута «публичная литературная дискуссия» «Ремаркизм или активизм?», состоявшаяся в Германии при участии Людвига Ренна [Лейтес 1930] ${ }^{3}$. Действительно, в журнале «Die neue Bücherschau» в июле 1929 г. вышла заметка «Remarquismus oder Aktivismus?» по мотивам этой дискуссии, подписанная Franz Hammel. B заметке цитируется то же самое высказывание Ренна, что и в «Литературной газете», дословно ${ }^{4}$ повторяется оно и в «ЛОКАФ» (по-видимому, фраза была переведена с немецкого оригинала):

Я вижу сегодня, что Ремарк и я совершили большую ошибку. Наши книги надо было писать совершенно иначе. Я написал свою книгу несколько лет назад, связанный с мелкобуржуазной идеологией, сегодня я знаю, что только один есть путь, ведущий к миру, - это последовательный путь пролетарской революции [ЛОКАФ 1931/2: 83; ср. Лейтес 1930] ${ }^{5}$.

Такая оценка Ремарка, однако, не помешала публикации вышеупомянутых переводов, кроме того, он продолжал входить в программы литкружков [ОР ИМЛИ. Ф. 53. Оп. 1. Ед. хр. 94. Л. 5]. Читатель и в первую очередь оборонный автор должны были прийти к выводу, что Ремарк и подобная его романам литература искажает истинное видение войны. Этому и должны были способствовать редакционные заметки. Редакция «ЛОКАФ» продолжала:

2 См., например, [Гельфанд 1931]. Эта статья, однако, вышла позже, чем случились первые упоминания ремаркизма в «ЛОКАФ».

3 Позже, в 1932 г., «ЛОКАФ» опубликовал статью Лейтеса «Как они “обыгрывают” войну? О новых тенденциях в буржуазной военной беллетристике», где тот критикует Ремарка за «пацифизм, вползающий в фашизм» [Лейтес 1932: 124].

4 С незначительными изменениями в пунктуации.

5 Cp.: Ich sehe heute ein, daß Remarque und ich einen großen Fehler begangen haben diese Bücher hätten anders geschrieben werden müssen. Mein Buch schrieb ich vor mehreren Jahren; damals war ich noch kleinbürgerlich befangen - heute weiß ich, daß nur ein Weg uns zum Frieden führt: der konsequente Weg der Revolution! [Hammel 1929]. 
Уже первая книга Ремарка [...] была [...] разоблачена, как выполнение конкретного социального заказа империализма; под маской пацифизма и внешней оппозиционности убедить трудящихся в том, что война - это рок, рок ужасный, кошмарный, но неотвратимый [ЛОКАФ 1931/2: 81].

Из этого заявления можно извлечь содержание понятия «пацифизм» в советской оборонной критике. Одной из своих целей ЛОКАФ видел «борьбу с пацифизмом», который считался маскировкой для подготовки новой войны. «Мирная советская политика», с другой стороны, должна была пацифизм разоблачить, чтобы быть готовыми к новой войне [Добренко 1993: 188-189]. Понятие «неотвратимости войны» также получало противоречивое наполнение. С одной стороны, критики в этом отношении обвиняли Ремарка в пацифизме и империализме. С другой оборонная литература, по сути, следовала одному из идеологических тезисов раннего сталинизма о неотвратимости классовой войны и готовила читателя к ней. Пацифизм, по мнению ЛОКАФ, с классовой войной никак не сочетался: «[...] в книге Ремарка [...] нет ни грана революции [...] Она парализует волю к протесту [...] Книги [sic!] Ремарка и ей подобные [...] идут в авангарде подготовки к новой войне» [ЛОКАФ 1931/2: 81].

Таким образом, от оборонного автора ожидалось, что он будет прославлять революцию каждый раз, когда говорит о войне. В противном случае он рискует оказаться в ситуации, когда критика назовет его империалистом, убеждающим трудящихся в том, что борьба бесполезна и они не смогут противостоять нападению.

Тем не менее о Ремарке и других авторах никогда не пишут, что они сознательные империалисты (Ремарка и вовсе называют автором «наивных обобщений» [ЛОКАФ 1931/2: 82]). Фактически это означает, что «правильная» советская оборонная литература должна заниматься перевоспитанием авторов. Им следует взглянуть на романы Ремарка и сделать наоборот. Редакторы «ЛОКАФ» также заявляют, что Ремарк даже не пытается дать происходящему социальную оценку, и это также сигнал для оборонного автора. Каждое его произведение должно соответствовать классовому пониманию империалистической войны и делать различие между империалистической и классовой войной.

В связи с Ремарком в советской оборонной критике также появляется понятие «героизм». В заметке утверждается, что «Ремарк пытается воскресить героику войны, идеологию войны» [ЛОКАФ 1931/2: 82] (складывается впечатление, что авторы заметки прочли роман несколько невнимательно). В этом состоит еще один парадокс оборонной литературы. С одной стороны, в ней нет места личному героизму, особенно когда речь идет о Первой мировой войне. С другой, в 1930-е гг. уже оформляется образ героя Гражданской войны [Закружная 2018: 
175-177]. Советский оборонный дискурс, таким образом, оказывается принципиально амбивалентен, и это касается не только «героизма», но и других понятий.

Закончив рассуждать о Ремарке, редакция делает несколько замечаний относительно мировой литературы: «Литературе, разливающей яд пацифизма, мы должны противопоставить свою подлинно-интернациональную, антимилитаристскую литературу» [ЛОКАФ 1931/2: 83]. Антимилитаризм в советской оборонной литературе оказывается противопоставлен пацифизму по линии «противостояние vs. капитуляция». Молодой автор должен видеть здесь четкое различие и постоянно спрашивать себя, а не ремаркист ли он.

Примененные к Ремарку категории оказались настолько удобными, что их использовали и применительно к самой советской литературе (наиболее показательна статья Николая Свирина ${ }^{6}$ «ротив пацифистских тенденций в советской литературе», вышедшая в том же году в номере 9 со сноской «Из речи на 4 пленума правления РАПП» [Свирин 1931а: 116]). Свирин использует те риторические паттерны, которые были опробова-

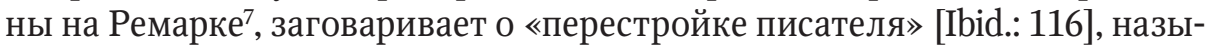
вает книгу советского автора «ремаркистской» [Ibid.: 117] и беспокоится по поводу «непонимания расстановки классовых сил» [Ibid.: 118].

Свирин, конечно же, не может не сослаться в своих рассуждениях на зарубежную литературу как отрицательный пример:

В последнее время мы сравнительно много уделяли внимания пацифизму в западной литературе. Это хорошо и совершенно необходимо. Однако, устремив взор на Запад, мы иногда не замечаем того, что делается у нас под носом. Мне кажется, важнейшая задача ЛОКАФ, важнейшая задача марксистской критики заключается сейчас в том, чтобы объявить решительный бой пацифистским иллюзиям и настроениям в советской литературе, драматургии и кино [Ibid.: 118; здесь и далее разрядка по источнику. - А. Б.].

Именно в этой статье, как кажется, виден процесс переноса понятия «пацифизм» на советскую литературу. Оно ставится знаком того, перестроился писатель или нет. Корни пацифизма Свирин, разумеется, находит в «социально-экономических условиях дореволюционной России»

6 Один из ключевых членов ЛОКАФ, был, в частности, ответственным редактором ленинградского «Залпа».

7 Надо сказать, что, в частности, понятие «пацифизм» и на идеологической уровне опробовано было сначала на иностранных публицистах и политических деятелях. См. [Ленин 1973]; по информации, указанной в Полном собрании сочинений, статья Ленина «Пацифизм буржуазный и пацифизм социалистический» была написана в 1917 г., но опубликована (а значит, включена в идеологический контекст) только в 1924 г. 
[Свирин 1931: 118]. При этом Свирин смешивает понятия «пацифизм» и «антимилитаризм», что противоречит установке, обозначенной в редакционной заметке о Ремарке, где эти две вещи противопоставлялись. Есть, таким образом, антимилитаризм, приравниваемый к пацифизму, и антимилитаризм, ему противопоставленный ${ }^{8}$.

Тональность оценки Ремарка в 1934 г., когда роман был опубликован в «Знамени» в переводе Горкиной, в целом не изменилась. На этот раз предваряющая заметка не была анонимной, ее написал Карл Радек, который ранее выступил автором предисловия к «На Западном фронте без перемен» (1929)9. Озаглавленная «Мелкий буржуа возвращается с войны», заметка в целом повторяла оценки 1931 г. Называя Ремарка «выхолощенным мелким буржуа» [Радек 1934: 17], Радек таким образом проводит черту между ним и советским оборонным автором. Тот вновь получает дополнительный сигнал о том, что на Ремарка ориентироваться не стоит. Заметка, однако, сосредоточена на самом Ремарке и других немецких авторах, конкретных рекомендаций в ней нет.

Другим характерным «отрицательным примером» для оборонного автора чуть было не стал Чарльз Гаррисон. Отрывок из его романа «Generals Die in Bed» был опубликован в номере 4 за тот же 1931 г. Гаррисону достались чуть более мягкие оценки, чем Ремарку. В начале редакторы «ЛОКАФ» заявляют: «Чарльз Гаррисон - несомненно талантливый эпигон Ремарка - в некоторых своих положениях идет дальше, чем Ремарк» [ЛОКАФ 1931/4]. Неожиданно авторы заметки признают, что «Ремарк очень логичен в подаче материала. Он сохраняет "скорлупу объективности” в своем отношении к ужасам и явлениям войны. Он монтирует композицию увлекательно и дает трагедию так, что она притягивает и возбуждает» [Ibid.]. Оборонному автору, таким образом, на этом этапе разрешается заимствовать у Ремарка или Гаррисона формальные приемы изображения.

Далее в заметке говорится: «Но на ряду [sic!] с несомненными художественными достоинствами [...] читатель ясно видит, что ремаркисты тщательно избегают ВЫВОДОВ. Их книги - гигантские знаки вопроса» [ЛОКАФ 1931/4]. Характерно, что авторы заметки обобщают круг авторов, похожих на Ремарка, называя их «ремаркистами». Ремарк, таким образом, становится знаковым автором для советской оборонной литературы, занимающим противоположный формирующемуся канону полюс.

8 Надо сказать, что многие термины, которыми оперировали авторы критических статей «ЛОКАФ», имели конкретное идеологическое содержание, почерпнутое из работ Ленина, Сталина и проч. Случай с антимилитаризмом в статье Свирина, возможно, обусловлен оговоркой или редакторской невнимательностью. В целом же транслируемые оценки должны были быть вполне понятны современнику.

9 В предисловии понятие «ремаркизм» еще не встречается. 
Тезис о «знаках вопроса» в целом вписывается в концепцию «наивного автора». Ремарк и Гаррисон, по мысли авторов заметки, не знают ответов на вопрос об истоках войны, а советский оборонный автор должен задуматься над ним и дать единственный доктринально верный ответ. Советская литературная пропаганда не оставляет места для сомнения и ждет от писателя безапелляционных заявлений о том, откуда берется война и как она должна превратиться в классовую. Автор же вынужден следовать правилам этой игры, руководствуясь методом диалектического материализма, что бы под этим ни понималось.

Заметка о Гаррисоне завершается обобщением:

О войне, - говорим мы ремаркистам - можно писать только против войны, - вернее, - за войну гражданскую, ведущую нас к революции.

Но для этого нужна решимость бойца, а не печальные размышления обиженного пацифиста [ЛОКАФ 1931/4].

Таким образом окончательно закрепляется антитеза: империалистическая война или классовая, борьба или пацифизм. Этот тезис был обращен, разумеется, не к Ремарку и Гаррисону10, а к писателю, желающему напечататься в «ЛОКАФ».

Рисуя обобщенный образ ремаркиста, авторы заметки прямо называют Гаррисона эпигоном Ремарка, хотя никаких прямых сведений о том, что роман «Генералы умирают в постели» был создан под влиянием Ремарка, нет. Более того, отрывок из романа Гаррисон напечатал в американском коммунистическом журнале «New Masses» в июле 1929 г. [Harrison 1929a], едва ли не одновременно с выходом романа «На Западном фронте без перемен» на английском. Однако, желая закрепить понятие «ремаркизм» в собственном риторическом аппарате, чтобы в дальнейшем применять его к критикуемым авторам, и учитывая его популярность, редакция журнала, по-видимому, решила поставить Гаррисона выше Ремарка. В заметке утверждается, что Гаррисону до некоторой степени удалось продемонстрировать истоки империалистической войны и классового конфликта, так как он разделил своих героев на две противоборствующие группы. Таким же образом должен был эволюционировать и советский автор в том случае, если его произведения оценивались как пацифистские.

В ноябре 1931 г. в номере 11 журнала «ЛОКАФ» появляется краткая рецензия на роман Гаррисона в разделе «Библиография» («Генералы умирают в постели» как раз недавно вышел в ГИХЛе в переводе

10 Показательна, однако, дважды повторенная у Радека претензия, что Ремарк ничего не ответил на высланную ему анкету, тем самым вновь разоблачив самого себя как буржуа, которая звучит едва ли не как личная обида [Радек 1934: 17, 18 ]. 
М. Волосова). Л. Гладков, автор рецензии, оценивает роман Гаррисона существенно выше, что его предшественники в четвертом номере ${ }^{11}$. Причина здесь вполне очевидна: «Гаррисон принимает близкое участие в радикальном и революционном движении» [Гладков 1931: 149]. Открытая симпатия редакции «New Masses» по отношению к CCCP не может не повлиять на оценочные суждения о ее членах, к которым принадлежал Гаррисон. Более того, Гладков заявляет, что «[...] уже после того, как эта книга была переведена на русский язык и издана у нас, Гаррисон поместил в одной из крупных американских газет статью против ремаркизма» [Ibid.: 149]. Гаррисон действительно отрецензировал в «New Masses» два романа Ремарка - «На Западном фронте без перемен» [Harrison 1929b] и «Возвращение» [Idem 1931]. О первой книге Гаррисон пишет: «Мне [...] книга, пока я ее читал, показалась чем-то большим, чем просто литературой о войне - это сама война» ${ }^{12}$, затем, впрочем, замечает, что Ремарк неправ в том, что войну забудут: «Те из нас, кто прошел войну, не забудут ее никогда [...] это то, что отъявленные милитаристы любят видеть на страницах книг о войне» ${ }^{13}$. Гаррисон критикует и образ «потерянного поколения», апеллируя к тому, что в то самое время, когда герой Ремарка предается «пораженческим размышлениям» ${ }^{14}$, «[...] [н]а улицах Берлина строят баррикады люди не старше Ремарка» ${ }^{15}$ [Idem 1929b: 18-19]. Тем не менее в конце Гаррисон хвалит книгу как «достойный образец реализма» ${ }^{16}$, отдавая, впрочем, предпочтение Дж. Дос Пассосу [Ibid.: 19]. Что касается «Возвращения», здесь Гаррисон уже критикует Ремарка за отрицание революции: «Что ж, для Ремарка революция - это конец солдатского товарищества. Брат сражается с братом. Земляк сражается с земляком. Как жаль, говорит он, и если есть в книге какой-то “посыл”, то он таков» ${ }^{17}$ [Idem 1931: 17]. Гаррисон, очевидно, не доходит до таких обобщений, которые приписывает ему Гладков.

Первая рецензия, написанная в 1929 г., не согласуется с утверждением о том, что Гаррисон был эпигоном Ремарка. Сдержанная критика

11 В номере 6 вышеупомянутого «Залпа» за 1932 г. также вышла рецензия на «Генералы умирают в постели». По сути, она повторяет оценки Гладкова.

12 To me [...] the book seemed, as I read it, something more than a mere piece of war literature-it was war itself. Здесь и далее перевод наш.

13 Those of us who have lived through the war will never forget it [...] it is the sort of stuff which the arrant militarist likes to see written about war.

${ }^{14}$ Defeatist thoughts.

${ }^{15}$ In the streets of Berlin the barricades are lined by men no older than Remarque.

16 Fine piece of realism.

17 Well, to Remarque, revolution is the end of soldierly companionship. Brother fights brother. Townsman fights townsman. This is regrettable, he says, and if the book has any "message" this is his message. 
Гаррисона в целом даже не противоречит тому, что написано о Ремарке в редакционной заметке «ЛОКАФ». По всей видимости, редакция поторопилась причислить симпатизирующего СССР автора к ремаркистам и, осознав свою ошибку, поставила перед Гладковым задачу охарактеризовать Гаррисона иначе. В рецензии он оказывается уже не ремаркистом, а «анти-ремаркистом» (здесь видно, как быстро может поменяться «оборонная» оценка, формируя при этом еще одну оппозицию). Тем не менее Гладков не может написать рецензию, которая опровергала бы написанное в номере 4. Поэтому его оценка строится на том, что, когда Гаррисон писал роман, он был «мелкобуржуазным гуманистом». Здесь в оборот вводится еще одна категория, хорошо знакомая оборонному литератору. Наряду с пацифизмом в журнале осуждался гуманизм, который также трактовался как подготовка к новой войне [Добренко 2000: 229]. Ситуация с понятием «гуманизм» в советской литературной критике в начале 1930-х гг. была, впрочем, несколько сложнее, чем с пацифизмом. На позициях отрицания гуманизма, который, по-видимому, понимался как отказ от классовой борьбы, находилась РАПП, с которой ЛОКАФ часто сходился в оценках ${ }^{18}$. В связи с дискуссией вокруг «Перевала» и его представлениях о «новом гуманизме» рапповцы отвергали само это понятие применительно к литературе соцреализма [Белая 2000: 253-254]. Однако в 1934 г. Горький противопоставил буржуазному гуманизму «гуманизм Маркса - Энгельса - Сталина, - гуманизм, цель которого - полное освобождение трудового народа всех рас и наций из железных лап капитализма» [Горький 1934]. «ЛОКАФ» успел переориентироваться еще раньше и, уже будучи «Знаменем», опубликовал в номере 6 за 1933 г. рассказ Н. Огнева «Гуманность», где герои спорят о разных ее типах. Тем не менее, в 1931 г. «ЛОКАФ» отрицает его полностью и даже публикует в номере 12 статью «Против воронщины и гуманизма», где, по сути, повторяет тезис Леопольда Авербаха о том, что гуманизм несовместим с классовой борьбой. Так формируется еще одна линия аксиологии критических статей в «ЛОКАФ».

Относительно ремаркизма Гладков в оценках выступает также осторожнее, чем его предшественники. Гаррисон уже не ремаркист, но на его романе «в сильнейшей степени сказалось влияние ремаркизма» [Гладков 1931: 149]. Ремаркизм, таким образом, понятийно становится шире отсылок к Ремарку - не обязательно быть его эпигоном, чтобы воспроизводить похожие принципы изложения. Характерно, что Гладков повторяет мысль о «выводах», высказанную редакцией в номере 4:

18 О связи ЛОКАФ с РАПП см. [Добренко 2000: 228-229]. См. также статью Рейзина «Лицом к творческим вопросам», где тот указывает на «неразрывную идейно-политическую связь с РАППом» [Рейзин 1931: 138]. 
Он не делает тех выводов, которые сделал бы пролетарский художник. Гаррисон только констатирует факты, дает эмпирические зарисовки виденного им в империалистической войне. И, наконец, Гаррисон, как и Ремарк, против всякой войны. Он прежде всего гуманист и пацифист. Но в романе Гаррисона есть элементы подлинной революционности [Ibid.].

Сравнение с Ремарком появляется, но идет уже не по принципу эпигонства. Ремаркизм начинается восприниматься как «поветрие», охватившее зарубежную и отчасти советскую литературу. Фактически это понятие отделяется от Ремарка как такового. Ситуация «писатель не может сделать выводов» удачно экстраполируется на советского автора - именно он, а не Гаррисон будет адресатом этой рецензии. Выводы, разумеется, очевидны и должны осмысляться в контексте классовой борьбы.

Тем не менее Гладков в рецензии выступает, по сути, адвокатом писателя, утверждая, что «путь Гаррисона это путь к пролетариату» [Гладков 1931: 149]. К пролетариату Гладков отсылает и в связи с интернационализмом: «И в самом романе мы легко можем найти свидетельства этого интернационализма, но пока еще не классового, пролетарского. А интернационализма гуманистического и пацифистского» [Ibid.]. Оборонная риторика здесь вновь амбивалентна. Скоро она породит два вида гуманизма, а на этапе 1931 г. уже заводится речь о двух интернационализмах, противопоставленных по тому же принципу, что пацифизм и антимилитаризм. Гладков, транслирующий установки объединения, пытается конкретизировать, что такое настоящая оборонная литература, за счет введения еще одной переменной.

Эволюцию автора, пишущего о войне, Гладков видит следующим образом:

[...] мировоззрение Гаррисона ближе к мировоззрению революционного пролетариата, он более отчетливо, чем Ремарк (хотя еще в этом Гаррисон далеко отстал от художников пролетариата), видит причины, вызвавшие империалистическую войну, а вместе с тем и начинает понимать классовые противоречия, заложенные в капиталистическом обществе. Он художественно ярко и убедительно показывает, как солдатская масса начинает также осознавать эти противоречия [Гладков 1931: 149-150].

Гаррисон для Гладкова - способный ученик, который пишет, ориентируясь на коммунистическую повестку. Однако он характеризуется как отстающий от безупречной пролетарской культуры. Самоуверенность автора статьи в целом характерна для критиков «ЛОКАФ»- иностранному автору есть чему поучиться у признанных пролетарских художников. Фактически речь идет о том, что у любого писателя есть шанс исправиться и воспринять художественные принципы соцреализма и, в 
частности, ЛОКАФ. Приведенная цитата также встраивается в характер работы с «попутчиками» - ЛОКАФ всячески стремился привлечь их на свою сторону.

Так как Гаррисон остается недостаточно пролетарским художником, Гладков повторяет обозначенные его предшественниками характеристики: «Правда, здесь нет еще сознания необходимости революции. [...] И эта половинчатость, неумение, а может быть и боязнь сделать решительные выводы [курсив наш. - А. Б.] довлеет над всей книгой» [Гладков 1931: 150]. Предшественники Гладкова в номере 4 также сводили недостатки «ремаркистов» к отсутствию выводов, волновавших редакцию до такой степени, что слово даже было целиком набрано прописными (см. вышеприведенную цитату). Гладков, скорее всего, повторяет эту мысль сознательно. Эта зацикленность на необходимости выводов должна была отображаться в произведениях советских авторов парадоксальным образом: выводы, к которым должны органически прийти писатели, на самом деле заранее известны. Гаррисон виноват в том, что никто ему их не подсказал, но советского автора можно направить в нужную сторону.

Разумеется, Гладков в своей рецензии не может обойти пацифизм и гуманизм, высказываясь уже конкретнее, чем редакция в номере 4:

«Общечеловеческий» гуманизм и пацифизм, стремление никого не обвинять, а дать лишь эмпирическую фотографию событий, т. е. все то, что характерно для творческого метода Ремарка, в очень значительной мере характерно и для романа Гаррисона.

Поэтому, говоря о книге Гаррисона, необходимо говорить и о ремаркизме, как об одном из опаснейших и распространеннейших течений в западной литературе о войне, течений, оказывавших иногда сильное воздействие и на наших советских писателей.

$[\ldots]$

Гаррисон и Ремарк ненавидят войну вообще, т.-е. не делают различия между войной революционной и войной реакционной.

$[\ldots]$

И наша задача, задача марксистской критики, бороться с «буржуазно-демократическим осуждением войны вообще» [Гладков 1931: 150-151].

Гладков корректирует понятие гуманизма ремаркистов, называя его «общечеловеческим», однако еще не доходит до противопоставления его пролетарскому, как это будет сделано позднее. Противореча сам себе, Гладков вновь возвращается к определению Гаррисона как ремаркиста, хотя и выражается аккуратно. Показательна здесь уже прямая апелляция к адресатам рецензии - советским писателям, они, как и Гаррисон, должны идти по пути сопротивления ремаркизму. Наконец, противопоставляются реакционная и революционная войны, осуждается 
из них только первая. Однако в конце Гладков заявляет: «Гаррисон писатель, идущий к нам, а не от нас» [Гладков 1931: 151]. И далее:

И лишь тогда, когда мировоззрение революционного пролетариата станет мировоззрением Гаррисона, пессимизм деклассированого мелкого буржуа сменится оптимизмом класса, верящего в свою победу [Ibid.].

Автор рецензии выступает с позиции демиурга оборонного литературного процесса. Гаррисон - и тем более Ремарк - вряд ли могли бы напрямую воспринять этот призыв (как кажется, Гаррисон был бы в большой степени удивлен тем, чем его сначала записали в ремаркисты, затем в антиремаркисты, а после все же пришли к выводу, что он испытывает влияние ремаркизма как литературного феномена). Эта рецензия закрепляет обозначенный выше тезис: ремаркизм шире самого Ремарка, это уже не просто влияние конкретного автора, это тенденция, которой советскому оборонному писателю следует опасаться, прибегая к самоцензуре.

Соцреализм был объявлен единственно верным литературным методом позже, однако оборонная литература органично в него влилась. По выражению Добренко, «[с]оцреализм есть нормативная эстетика особого рода. [...]. Эта норма определяет не “творчество”, как обычно, но саму ситуацию творчества» [1999: 132; курсив Добренко. - А. Б.]. Советская оборонная литература на начальном этапе развития видела своей целью не просто привлечь писателей на свою сторону, но перевоспитать их, в том числе действуя от противного. Случай Ремарка и Гаррисона показателен в том смысле, что в начале 1930-х гг. редакции журнала «ЛОКАФ» было важно не только охарактеризовать «неправильные» тексты, но и вновь продемонстрировать их потенциальному автору. Читателю романы Ремарка и Гаррисона были и без того доступны, но их появление на страницах журнала свидетельствовало об особом внимании объединения. Критический анализ иностранных писателей становился одним из факторов формирования канона оборонной литературы, выстраивая круг анти-образцов. 1931 год, когда эти анти-образцы появились на страницах «ЛОКАФ», Х. Гюнтер относит к началу фазы канонизации соцреализма, «в которой канон формируется как более-менее систематическое целое по отношению к другим традициям» [Гюнтер 2000: 281]. Однако канону оборонной литературы необходим свой, по выражению Гюнтера, строительный материал, и его не всегда хватает (среди образцов военного романа, возникших в предшествующей фазе, Гюнтер называет «Разгром» Фадеева). Отсюда, как кажется, и возникает негативистская риторика оборонной критики, пытающейся жестко обозначить свои требования к автору, но не всегда находящая для этого ресурсы. Такая риторика в целом характерна для критики периода соцреализма: 
Наряду с позитивными нормами, канон соцреализма имеет ярко выраженную исключающую функцию, направленную против различных отклонений прежде всего «модернистского» характера. Отрицающий потенциал канона с наибольшей полнотой проявляется в фазе его полноценного функционирования в течение двух десятилетий, то есть до начала 1950-х гг. Борьба против отклонений ведется с тем, что классифицируется как «формализм», «натурализм», «субъективизм», «объективизм» и т. д. [Гюнтер 2000: 285].

В 1931 г. эта «отрицающая эстетика» только формируется и «ЛОКАФ», наряду с перечисленными Гюнтером отклонениями, разрабатывает собственные дефиниции, которые работают в действительности не на литературном, а на общем идеологическом уровне ${ }^{19}$ : «пацифизм», «гуманизм», «антимилитаризм», «интернационализм», причем семантическое наполнение негативных понятий значительно полнее, чем позитивных. Критика, направленная против Ремарка и Гаррисона, становится в том числе полем для апробации риторики «ЛОКАФ» по отношению к советским авторам. Кроме того, в случае с Гаррисоном это и риторика перевоспитания автора, очерчивающая для него возможную стратегию.

Понятийный аппарат рецензий на произведения Ремарка и Гаррисона на советских авторов критики «ЛОКАФ» действительно переносили (см., например, упомянутую выше статью Свирина). Так, в номере 8 за 1931 г. вышла рецензия Павла Березова на книгу В. Арамилева «В дыму войны. Записки вольноопределяющегося» (1930). Критик обвиняет автора в «перепевах ремаркизма», «разбавленном ремаркизме» ${ }^{20}$ и «простом подражании Ремарку» [Березов 1931: 137-138]. В номере 11 «мелкобуржуазным пацифистом» назван герой книги Александра Воронского «Глаз урагана» (1931) [Зубковский 1931: 147], а в следующем номере опубликована уже упомянутая статья И. Зубковского «Против воронщины и гуманизма (О книге П. Федотова “Военкоры”)». Не удается избежать обвинений в «непреодоленном ремаркизме» даже Николаю Тихонову, члену ЛОКАФ [Мирин 1932: 165]. В номере 4 за 1932 г. по поводу книги Тихонова «Война» (1931) вышла статья Рейзина «Победы и поражения»,

19 См. упомянутый выше пример с понятием «пацифизм», которое переносится в литературную критику из работ Ленина. Ср. замечание Гюнтера: «Нормы, определяющие соцреалистический канон, формулируются на разных уровнях. Можно различать четыре дискурса: 1 . общий идеологический дискурс, т. е. идеология марксизма-ленинизма; 2. литературно-политический дискурс, который включает в себя идеологические постулаты, такие как, например, партийность, типичность, революционная романтика, народность и т. д.; 3. металитературный дискурс, т. е., в первую очередь, литературную критику, которая конкретизирует «художественный метод» соцреализма, применяя его к литературным текстам; 4. собственно литературный дискурс, в котором сформулированы определенные стилевые нормы и запреты» [Гюнтер 2000: 281].

20 Надо сказать, что и здесь критик признает «художественный талант» Ремарка [Березов 1931: 138], которого Арамилеву не хватает. 
напечатанная по стенограмме доклада на московском активе ЛОКАФ. В статье реализуется представление об «идейно-творческой перестройке автора» ${ }^{21}$, в том числе приводятся его слова: «Для меня ясно, что сейчас я не могу написать ни одного произведения, которое не предусматривало бы политического содержания. Мне кажется, что произведения без политики сейчас быть не может» [Рейзин 1932: 145-146]. В этом отношении «Война» противопоставлена книгам Ремарка, который, по мнению Рейзина эксплицитно ставит себя вне политики, хотя его творчество в действительности «[...] насквозь проникнуто, политикой, ибо, скрывая от масс, что война являлась продолжением империалистической политики [...] служит делу подготовки новой войны» [Рейзин 1932: 146]. За ремаркизм Рейзин Тихонова уже не упрекает, однако к перестроившемуся автору выдвигается новое требование - не просто избегать ремаркизма и пацифизма, а бороться с ними. Этого, по мнению критика, Тихонову не удалось, несмотря на то что книга «задумана как удар по ремаркизму» [Рейзин 1932: 147-148]. В конце статьи Рейзин закрепляет тезис о перевоспитании писателя: «[...] путь Тихонова от “Орды” и “Браги” до “Кочевников” и “Войны” есть типичнейший путь перестройки писателей из попутчиков в союзники пролетарской литературы» [Рейзин 1932: 149]. Во всех упомянутых статьях и рецензиях воспроизводятся клише, применявшиеся к зарубежной литературе. Советскому автору, если он хотел войти в круг оборонных и напечататься в «ЛОКАФ», который во многом транслировал государственную военную пропаганду, в этой ситуации не оставалось ничего другого, как принять эти правила игры.

Позднее, в конце 1950-х - начале 1960-х гг. понятие «ремаркизм» вновь распространяется по тому же принципу: сначала применительно к самому Ремарку и похожей иностранной литературе, а затем к так называемой «лейтенантской прозе». Ср. характерное высказывание В. Кирпотина в газете «Известия»:

“Ремаркизм” - это определенное умонастроение, определенное мировоззрение, которое подавляет активность и порождает пассивность в человеке, преобразуя его праведный гнев в одурманенное алкоголем отчаяние. "Ремаркизм” - это философия, соблазнительная для растерянных, не находящих себе места интеллигентиков, для людей, ищущих, чем оправдать свою никчемность, а иногда и свое разложение [Кирпотин 1959].

Упоминание «ремаркизма» оказалось удачным приемом даже тогда, когда риторика классовой борьбы уже не была столь актуальна.

21 В 1920-е гг. Тихонов входил в объединение «Серапионовы братья». 


\section{Сокращенные названия архивов}

ОР ИМЛИ РАН - Отдел рукописей Института мировой литературы Российской академии наук РГАЛИ - Российский государственный архив литературы и искусства

\section{Библиограсрия}

\section{ИСТОЧНИКИ}

Березов 1931

Березов П., В. Арамилев - «В дыму войны» - записки вольноопределяющегося, ЛОКАФ, 1931, 8, 136-139

Гельфанд 1931

Гельфанд М., Ремаркизм, Литература мировой революции, 1931, 10, 114-116.

Гладков 1931.

Гладков Л., Чарльз Гаррисон - «Генералы умирают в постели», ЛОКАФ, 1931, 11, 149151.

Горький 1934

Горький А. М., Пролетарский гуманизм, Правда, 1934, 140.

Зубковский 1931

Зубковский И., А. Воронский - «Глаз урагана», ЛОКАФ, 1931, 147-149.

Кальм 1930

Кальм Д., Создано Литературное объединение Красной Армии и Флота, Литературная газета, 1930, 33 (70).

Кирпотин 1959

Кирпотин В., Без путеводной звезды, Известия, 1959, 273.

ЛОКАФ 1931/2

От редакции, ЛОКАФ, 1931, 2, 81-83.

ЛОКАФ 1931/4

[От редакции], ЛОКАФ, 1931, 4, 60.

ЛОКАФ 1931/5-6

Литкружковцам Красной армии и флота, ЛОКАФ, 1931, 5-6, 175.

Лейтес 1930

Лейтес А., Ремаркизм или активизм?, Литературная газета, 1930, 23 (60).

Ленин 1973

Ленин В. И., Пацифизм буржуазный и пацифизм социалистический, Idem, Полное собрание сочинений, 30, Москва, 1973, 241-260.

Мирин 1932

Мирин Н., Тихонов «Война», ЛОКАФ, 1932, 3, 163-166.

Поляк 1930

Поляк М., Организуем ЛОК, Первый Залп. Вторая очередь, 1930, Март, 3

Радек 1934

Радек К., Мелкий буржуа возвращается с войны, Знамя, 1934, 7, 17-20.

Рейзин 1931

Рейзин С., Лицом к творческим вопросам, ЛОКАФ, 1931, 4, 133-141.

Рейзин 1932

Рейзин С., Победы и поражения, ЛОКАФ, 1932, 4, 140-149 
The Soviet Journal LOKAF on Foreign Literature:

How not to Become Remarquable

Свирин 1931а

Свирин Н., Против пацифистских тенденций в советской литературе, ЛОКАФ, 1931, 9, 116-119.

Hammel 1929

Hammel F., „Remarquismus oder Aktivismus?“, Die neue Bücherschau, 1929, 7, 393.

Harrison 1929a

Harrison Ch., Generals Die in Bed, New Masses, 1929, 5/2, 12-13.

Harrison $1929 \mathrm{~b}$

Harrison Ch., Here Is War!, New Masses, 1929, 5/3, 18-19.

Harrison 1931

Harrison Ch., The Road Back by Erich Maria Remarque [...] The Kaiser's Coolies by Theodor Plivier, New Masses, 1931, 7/3, 17.

\section{Литература}

Белая 2000

Белая Г., Оппонирующее сознание: «Перевал», Соцреалистический канон, С.-Петербург, 2000, 249-266.

Бурдье 2005

Бурдье П., Поле литературы, Idem, Социальное пространство. Поля и практики, С.-Петербург, Москва, 2005, 365-473.

Геллер, Боден 2000

Геллер Л., Боден А., Институциональный комплекс соцреализма, Соцреалистический канон, С.-Петербург, 2000, 289-319.

Гюнтер 2000

Гюнтер Х., Жизненные фазы соцреалистического канона, Соиреалистический канон, С.-Петербург, 2000, 281-288.

Гюнтер, Добренко 2000

Гюнтер Х, Добренко Е., ред., Соцреалистический канон, С.-Петербург, 2000.

Добренко 1993

Добренко Е., Метафора власти, Мюнхен, 1993. 1999

Добренко Е., Формовка советского писателя. Социальные и эстетические истоки советской литературной культуры, С.-Петербург, 1999.

2000

Добренко Е., Оборонная литература и соцреализм: ЛОКАФ, Соцреалистический канон, С.-Петербург, 2000, 225-241.

Закружная 2018

Закружная 3. С., Принципы изображения героя Гражданской войны в литературнокритических выступлениях членов ЛОКАФ (по материалам архива ОР ИМЛИ РАН), Вестник славянских культур, 2018, 49, 171-184.

Закружная 2019

Закружная 3. С., Литературное объединение Красной армии и флота и Союз советских писателей: к вопросу об истоках соцреализма, Studia Litterarum, 2019, 4/2, 44-61.

Закружная, Московская 2018

Закружная 3. С., Московская Д. С., Институциональное измерение советской литературы. К истории забытого литературного объединения ЛОКАФ, Филологический класс, 2018, 2 (52), 12-18. 
Сысоева 2019

Сысоева А. В., Создание советской военной пропаганды в Ленинграде начала 1930-х годов: новый метод работы с писателями, Русская литература, 2019, 4, 159-165. 2020

Сысоева А. В., Военизаторские курсы 1931 года в Ленинграде как способ формирования советской оборонной литературы, Новое литературное обозрение, 2020, 4 (164), 123 134.

Guillory 1993

Guillory J., Cultural Capital: The Problem of Literary Canon Formation, Chicago, 1993.

Lovell 2000

Lovell S., The Russian Reading Revolution. Print Culture in the Soviet and Post-Soviet Eras, New York, 2000.

Malygin 2012

Malygin E., Literatur als Fach in der sowjetischen Schule der 1920er und 1930er Jahre. Zur

Bildung eines literarischen Kanons, Bamberg, 2012.

\section{References}

Belaya G., Opponiruiushchee soznanie: "Pereval”, Sotsrealisticheskii kanon, St. Petersburg, 2000, 249-266.

Bourdieu P., Le champ littéraire, Idem, Sotsial'noe prostranstvo. Polia i praktiki, St. Petersburg, Moscow, 2005, 365-473.

Dobrenko E., Formovka sovetskogo pisatelia. Sotsial'nye i esteticheskie istoki sovetskoi literaturnoi kul'tury, St. Petersburg, 1999.

Dobrenko E., Metafora vlasti, Munich, 1993.

Dobrenko E., Oboronnaia literatura i sotsrealizm, Sotsrealisticheskii kanon, St. Petersburg, 2000, 225-241.

Geller L., Boden A., Institutsional'nyi kompleks sotsrealizma, Sotsrealisticheskii kanon, St. Petersburg, 2000, 289-319.

Guillory J., Cultural Capital: The Problem of Literary Canon Formation, Chicago, 1993.

Günther H., Dobrenko E., eds., Sotsrealisticheskii kanon, St. Petersburg, 2000.

Günther H.,Zhiznennye fazy sotsrealisticheskogo kanona, Sotsrealisticheskii kanon, St. Peterburg, 2000, 281-288.

Lovell S., The Russian Reading Revolution. Print Culture in the Soviet and Post-Soviet Eras, New York, 2000.
Malygin E., Literatur als Fach in der sowjetischen Schule der 1920er und 1930er Jahre. Zur Bildung eines literarischen Kanons, Bamberg, 2012.

Sysoeva A. V., Emergence of the Soviet Military Propaganda in Leningrad of the Early 1930th: The New Method of Working with Writers, Russkaia Literatura, 2019, 4, 159-165.

Sysoeva A. V., The Militarization of Writers in Leningrad in 1931 as a Means of Creating Soviet Defense Fiction, Novoe literaturnoe obozrenie, 2020, 4 (164), 123-134.

Zakruzhnaya Z. S., Literary Association of the Red Army And Navy and The Union of Soviet Writers: Unpacking The Origins of Social Realism. Studia Litterarum, 2019, 4/2, 44-61.

Zakruzhnaya Z. S., Moskovskaia D. S., Institutional aspect of Soviet literature. History of the forgotten Literary Association of the Red Army and Navy, Filologicheskii klass, 2018, 2 (52), 12-18.

Zakruzhnaya Z. S., Principles of Representation of the Civil War Hero in Literary Criticism of "LOKAF" Members (Based on Materials of the Department of Manuscripts of the IWL RAS). Vestnik slavianskikh kul'tur, 2018, 49, 171-184.

\author{
Алиа Олеговна Бурцева, \\ независимый исследователь \\ Москва \\ Россия / Russia \\ alla.burtseva@gmail.com
}

